\title{
TATA CARA DAN PROSEDUR UNTUK MEMPEROLEH HAK PATEN UNTUK INVENSI IKAT PINGGANG ULTRASONIK SEBAGAI ALAT BANTU TUNANETRA
}

\author{
Dedy Febriyan \\ 155100014 \\ Fakultas Komputer, 448757180 \\ Dedyfebriyan.student@umitra.ac.id
}

\begin{abstract}
Telah banyak diciptakan alat bantu mobilitas bagi penyandang tunanetra sebagai pengguna, namun masih sedikit memiliki fungsi yang lebih kompleks dalam mendeteksi objek atau halangan baik yang berada didepan maupun disamping pengguna ketika melakukan mobilitasnya. Hal ini disebabkan belum diaplikasikanya sensor sebagai pendeteksi objek dalam jarak dan jangkauan yang lebih optimum, dan belum dikembangkan dalam bentuk yang lebih efisien dan lebih fashionable bagi pengguna seperti dalam penelitian ini diaplikasikan 3 sensor yaitu PING dan SRF05 yang akan memaksimalkan fungsi dari alat bantu ini dengan rancangan output berupa getar dan suara dengan jangkuan antara $3 \mathrm{~cm}$ hingga $3 \mathrm{~m}$. Dari hasil pengukuran didapatkan bahwa tegangan keluaran sensor PING dan SRF05 berbanding lurus dengan pertambahan jarak deteksi terhadap objek dan kedua sensor tersebut membutuhkan waktu pantul masing-masing $74 \mathrm{~ms}$ dan $91 \mathrm{~ms}$ untuk jarak $10 \mathrm{~cm}$.
\end{abstract}

\section{Sensor Ultrasonik}

Gelombang ultrasonik merupakan gelombang akustik yang memiliki frekuensi mulai $20 \mathrm{kHz}$ hingga sekitar $20 \mathrm{MHz}$. Frekuensi kerja yang digunakan dalam gelombang ultrasonik bervariasi tergantung pada medium yang dilalui, mulai dari kerapatan rendah pada fasa gas, secara matematis besarnya jarak dapat dihitung sebagai berikut:

$\mathrm{S}=\mathrm{v} \cdot \mathrm{t}$

Dimana $s$ adalah jarak dalam suatu meter, v adalah kecepatan suara yaitu 344 $\mathrm{m} /$ detik dan $t$ adalah waktu tempuh dalam satuan detik. Ketika gelombang ultrasonik menumbuk suatu penghalang maka sebagai gelombang tersebut akan dipantulkan sebagian diserap dan sebagian yang lain nya akan diteruskan. Sensor ultrasonik adalah sebuah sensor yang mengubah besaran fisis (bunyi) menjadi besaran listrik. Pada sensor ini gelombang ultrasonik dibangkitkan melalui sebuah benda yang disebut piezoelektronik. Piezoelektronik ini akan mengasilkan gelombang ultrasonik dengan frekuensi $40 \mathrm{kHz}$ ketika sebuah osilator diterapkan pada benda tersebut.

Kata Kunci : Penerimaan dan Pengeluaran Kas.

\section{A. INTRODUCTION}

-Prosedur pendaftaran hak Paten. 
Untuk mendaftar hak paten bisa langsung mendaftarkan inovasi. Namun jika masih bingung atau tidak memiliki waktu untuk mendaftar bisa menggunakan jasa konsultan. Sebelum mendaftar bisa mengajukan semacam deskripsi mengenai inovasi anda. Biasa nya deskripsi tersebut mengenai berisi tentang latar belakang mengenai inovasi disertai dengan foto.

\section{Berikut prosedurnya}

Permohonan Paten diajukan dengan cara mengisi formulir

1. yang disediakan untuk itu dalam bahasa Indonesia dan diketik rangkap 4 (empat).

2. Pemohon wajib melampirkan:

surat kuasa khusus, apabila

a. permohonan diajukan melalui konsultan Paten terdaftar selaku kuasa;

surat pengalihan hak, apabila

b. permohonan diajukan oleh pihak lain yang bukan penemu;

deskripsi, klaim, abstrak:

c. masing-masing rangkap 3 (tiga);

d. gambar, apabila ada :
rangkap 3 (tiga);

\begin{tabular}{|c|c|c|}
\hline & e. & $\begin{array}{l}\text { bukti prioritas asli, dan } \\
\text { terjemahan halaman depan } \\
\text { dalam bahasa Indonesia } \\
\text { rangkap } 4 \text { (empat), apabila } \\
\text { diajukan } \\
\text { prioritas. }\end{array}$ \\
\hline & f. & $\begin{array}{l}\text { terjemahan uraian penemuan } \\
\text { dalam bahasa Inggris, apabila } \\
\text { penemuan tersebut aslinya } \\
\text { dalam bahasa asing selain } \\
\text { bahasa Inggris : rangkap } 2 \\
\text { (dua); }\end{array}$ \\
\hline & g. & $\begin{array}{l}\text { bukti pembayaran biaya } \\
\text { permohonan Paten sebesar } \\
\text { Rp. 575.000,- (lima ratus } \\
\text { tujuh puluh lima ribu rupiah); } \\
\text { dan }\end{array}$ \\
\hline & h. & $\begin{array}{l}\text { bukti pembayaran biaya } \\
\text { permohonan Paten Sederhana } \\
\text { sebesar Rp. 125.000,- } \\
\text { (seratus dua puluh lima ribu) } \\
\text { dan untuk pemeriksaan } \\
\text { substantif Paten Sederhana } \\
\text { sebesar Rp. 350.000,- (tiga } \\
\text { ratus lima puluh ribu rupiah); }\end{array}$ \\
\hline & i. & $\begin{array}{ll}\text { tambahan biaya setiap klaim, } \\
\text { apabila lebih dari } 10 \\
\text { klaim:Rp. } & 40.000 \text {,- per klaim. }\end{array}$ \\
\hline 3. & \multicolumn{2}{|c|}{$\begin{array}{l}\text { Penulisan deskripsi, klaim, } \\
\text { abstrak dan gambar sebagaimana } \\
\text { dimaksud dalam butir } 2 \text { huruf } \mathrm{c} \\
\text { dan huruf d ditentukan sebagai } \\
\text { berikut: }\end{array}$} \\
\hline & a. & $\begin{array}{l}\text { setiap lembar kertas hanya } \\
\text { salah satu mukanya saja yang }\end{array}$ \\
\hline
\end{tabular}


boleh dipergunakan untuk penulisan dan gambar;

deskripsi, klaim dan abstrak diketik dalam kertas HVS atau yang sejenis yang b. terpisah dengan ukuran A-4 $(29,7$ x $21 \mathrm{~cm})$ dengan berat minimum 80 gram dengan batas sebagai berikut:

\begin{tabular}{l|l|l}
$\begin{array}{l}\text { - dari pinggir } \\
\text { atas }\end{array}$ & $: 2 \mathrm{~cm}$ \\
\hline $\begin{array}{l}\text { - dari pinggir } \\
\text { bawah }\end{array}$ & $: 2 \mathrm{~cm}$ \\
\hline $\begin{array}{l}\text { kiri } \\
\text { dari pinggir }\end{array}$ & $:$ & 2,5 \\
\hline $\begin{array}{c}\text { dari pinggir } \\
\text { kanan }\end{array}$ & $: 2 \mathrm{~cm}$ \\
\hline
\end{tabular}

kertas A-4 tersebut harus berwarna putih, rata tidak mengkilat dan pemakaiannya dilakukan dengan

c. menempatkan sisinya yang pendek di bagian atas dan bawah (kecuali dipergunakan untuk gambar);

setiap lembar deskripsi, klaim dan gambar diberi nomor urut angka Arab pada

d. bagian tengah atas dan tidak pada batas sebagaimana yang dimaksud pada butir 3 huruf b (1); pada setiap lima baris pengetikan baris uraian dan klaim, harus diberi nomor baris dan setiap halaman baru merupakan permulaan (awal)

e. nomor dan ditempatkan di sebelah kiri uraian atau klaim serta tidak pada batas sebagaimana yang dimaksud pada butir 3 huruf b (3);

pengetikan harus dilakukan dengan menggunakan tinta (toner) warna hitam, dengan

f. ukuran antar baris 1,5 spasi, dengan huruf tegak berukuran tinggi huruf minimum 0,21 cm;

tanda-tanda dengan garis, rumus kimia, dan tanda-tanda

g. tertentu dapat ditulis dengan tangan atau dilukis;

gambar harus menggunakan tinta Cina hitam pada kertas h. gambar putih ukuran A-4 dengan berat minimum 100 gram yang tidak mengkilap dengan batas sebagai berikut:

\begin{tabular}{l|l|l}
$\begin{array}{l}\text { - dari pinggir } \\
\text { atas }\end{array}$ & $: 2,5$ \\
& & \\
& & \\
\hline - dari pinggir & $: 1 \mathrm{~cm}$ \\
bawah & & \\
\hline - dari pinggir & $:$ & 2,5 \\
kiri & $\mathrm{cm}$
\end{tabular}




$$
\begin{aligned}
& \text { - dari pinggir }: 1 \mathrm{~cm} \\
& \text { kanan }
\end{aligned}
$$

seluruh dokumen Paten yang diajukan harus dalam lembar-

i. lembar kertas utuh, tidak boleh dalam keadaan tersobek, terlipat, rusak atau gambar yang ditempelkan; setiap istilah yang dipergunakan dalam

j. deskripsi, klaim, abstrak dan gambar harus konsisten satu sama lain.

Penyandang tunanetra adalah seseorang dengan keterbatasan penglihatan. Ketika berjalan mereka lebih sering menggunakan alat bantu erupa tongkat untuk mengetahui halangan/keberadaan objek lain ataupun untuk mengetahui kontur jalan yang akan dilewati. Invensi ini berupa ikat pinggang ultrasonic yang berfungsi untuk menggantikan tongkat sebagai alat bantu tunanetra. Invensi ini terdiri dari 2 buah sensor ultrasonic dengan side object rejection yang diletakkan secara horizontal dan diagonal untuk mendeteksi adanya halangan di depan user dan untuk meneteksi halangan berupa lubang atau tanjakan/tangga yang ada pada kontur jalan yang akan dilewati oleh user. Pada invensi ini, data dari ke 2 sensor ultrasonic ini akandi prosses oleh mikrokontroller sebagai pusat kontrol data input/output seingga output peringatan berupa bunyi buzzer akan diaktifkan ketika mendeteksi adanya halangan yang berada pada rentang jarak $150 \mathrm{~cm}$ didepan user, dan output peringatan berupa getaran vibrator akan diaktifkan ketika pada kontur jalan terdeteksi adanya halangan berupa lubang /tangga yang memiliki perbedaan tinggi permukaan permukaan tanah mencapai lebih atau kurang dari $12,5 \mathrm{~cm}$ dari arak acuan/referensi kontur jalan.

\section{B. CONCLUSION}

- Sensor ultrasonik PING dan sensor ultrasonik SRF05 meniliki karakteristik yang sama yaitu tegangan keluaran pada sensor PING dan SRF05 tersebut sama-sama berbanding lurus dengan dengan pertambahan jarak deteksi terhadap obje.

- Untuk menempuh jarak sejauh $10 \mathrm{~cm}$, sensor ultrasonik PING membutukan waktu pantul gelombang selama $74 \mathrm{~ms}$, sedangkan sensor ultrasonik SRF05 membutuhkan waktu pantul gelombang selama $91 \mathrm{~s}$.

- Ketika berjalan mereka lebih sering menggunakan alat bantu erupa tongkat untuk mengetahui halangan/keberadaan objek lain ataupun untuk mengetahui 
kontur jalan yang akan

dilewati.

\section{ACKNOWLEDGEMENT}

University Of Indonesia

University Of Mitra Indonesia

Telkom University

University Of Mellbourne

Saitama University

\section{REFERENCE (Based ISO 690 )}

[1] A. S. Putra And O. M. Febriani, "Knowledge Management Online Application In Pdam Lampung Province," In Prosiding International 
Conference On Information Technology And Business (Icitb), 2018, Pp. 181-187.

[2] A. S. Putra, O. M. Febriani, And B. Bachry, "Implementasi Genetic Fuzzy System Untuk Mengidentifikasi Hasil Curian Kendaraan Bermotor Di Polda Lampung," J. Sist. Inf. Dan Manaj. Basis Data, Vol. 1, No. 1, Pp. 21-30, 2018.

[3] O. M. Febriani And A. S. Putra, "Sistem Informasi Monitoring Inventori Barang Pada Balai Riset Standardisasi Industri Bandar Lampung," J. Inform., Vol. 13, No. 1, Pp. 90-98, 2014.

[4] Putra, Arie Setya. "2018 Artikel Struktur Data, Audit Dan Jaringan Komputer." (2018).

[5] Putra, A. S. (2018, July 17). Paperplain Fundamental Create Application With Borland Delphi 7.0 University Of Mitra Indonesia. Retrieved From Osf.Io/Pbrn9.

\section{E. REFERENCE (Based APA)}

Putra, A. S., Aryanti, D. R., \& Hartati, I. (2018, November). Metode SAW (Simple Additive Weighting) sebagai Sistem Pendukung Keputusan Guru Berprestasi (Studi Kasus: SMK Global Surya). In Prosiding Seminar Nasional Darmajaya (Vol. 1, No. 1, pp. 85-97).
Sari, D. P., Febriani, O. M., \& Putra, A. S. (2018, November). Perancangan Sistem Informasi SDM Berprestasi pada SD Global Surya. In Prosiding Seminar Nasional Darmajaya (Vol. 1, No. 1, pp. 289-294).

Putra, A. S. (2018). Paperplain: Execution Fundamental Create Application With Borland Delphi 7.0 University Of Mitra Indonesia.

Putra, A. S., Sukri, H., \& Zuhri, K. Sistem Monitoring Realtime Jaringan Irigasi Desa (JIDES) Dengan Konsep Jaringan Sensor Nirkabel. IJEIS (Indonesian Journal of Electronics and Instrumentation Systems), 8(2), 221232.

Darmawan, A., Yuliawati, D., Marcella, O., \& Firmandala, R. (2016). Sistem Absensi dan Pelaporan Berbasis Fingerprint dan SMS Gateway. EXPLORE, 7(1).

Febriani, O. M., Wahyuni, T., \& Yusuf, S. (2017). DESIGN OF WEBSITE-BASED INFORMATION SYSTEM FOR EDOCUMENT ADMINISTRASI IN THE COMMUNITY SERVICE UNIT (A Case Study at Rajabasa District). INTERNATIONAL JOURNAL OF COMPUTERS \& TECHNOLOGY, 16(7), 7010-7020.

Febriani, O. M., \& Wahyuni, T. (2017, October). PERANCANGAN SISTEM E-DOCUMENT ADMINISTRASI LOGBOOK PENELITIAN PADA UNIT LAYANAN DI BANDAR LAMPUNG. In Prosiding Seminar 
Nasional Darmajaya (Vol. 1, No. 1, pp. 187-194).

Febriani, O. M., \& Permadi, A. B. (2017). Implementasi Sistem Aplikasi Data Bimbingan dan Pelanggaran Siswa pada Sekolah Menengah Atas di Lampung Tengah dengan Metode Analisis dan Desain Sistem Terdistribusi (SSAD). EXPERT, 7(1).

Febriani, O. M., \& Ambarwati, L. (2015). PERANCANGAN APLIKASI PENGOLAHAN DATA PENJUALAN UKM KELANTING KHAS TELO DESA SIDOHARJO KECAMATAN JATI AGUNG KABUPATEN LAMPUNG SELATAN. Jurnal Teknologi Informasi dan Bisnis Pengabdian Masyarakat Darmajaya, 1(1), 77-95.

Febriani, O. M. (2015). Rancang Bangun Aplikasi Ecommercemenggunakan Freewebstore pada UKM Kelanting di Desa Sidoharjo Lampung Selatan. Prosiding Sembistek 2014, 1(02), 446-458. 